\title{
Field Decomposition of Corn Cob in Seasonally Frozen Soil and Its Intrinsic Influencing Factors: The Case of Northeast China
}

\author{
Yu Zou ${ }^{1,2}$, Jun Fu ${ }^{1,2,3, *(D)}$, Zhi Chen ${ }^{2,3}$ and Luquan Ren ${ }^{1,2}$ \\ 1 Key Laboratory of Bionic Engineering, Ministry of Education, Jilin University, Changchun 130025, China; \\ zouyu19@mails.jlu.edu.cn (Y.Z.); lqren@jlu.edu.cn (L.R.) \\ 2 College of Biological and Agricultural Engineering, Jilin University, Changchun 130025, China; \\ caamschen@126.com \\ 3 Chinese Academy of Agricultural Mechanization Sciences, Beijing 100083, China \\ * Correspondence: fu_jun@jlu.edu.cn
}

check for

updates

Citation: Zou, Y.; Fu, J.; Chen, Z.; Ren, L. Field Decomposition of Corn Cob in Seasonally Frozen Soil and Its Intrinsic Influencing Factors: The Case of Northeast China. Agriculture 2021, 11, 556. https://doi.org/ 10.3390/agriculture11060556

Academic Editors: Mohsin Tanveer, Mirza Hasanuzzaman and Ejaz Ahmad Khan

Received: 18 May 2021

Accepted: 14 June 2021

Published: 17 June 2021

Publisher's Note: MDPI stays neutral with regard to jurisdictional claims in published maps and institutional affiliations.

Copyright: (c) 2021 by the authors. Licensee MDPI, Basel, Switzerland. This article is an open access article distributed under the terms and conditions of the Creative Commons Attribution (CC BY) license (https:/ / creativecommons.org/licenses/by/ $4.0 /)$.

\begin{abstract}
Returning corn cobs to the field during corn kernel harvesting is an effective way to improve soil properties and increase crop yield. However, seasonally frozen soil seriously hinders the field decomposition process of corn cobs. To explore the decomposition characteristics and promote field decomposition, in this study, the nylon mesh bag method was used to perform field decomposition tests for 150 days. Fiber composition analysis and microstructure observation were carried out. The results showed that the field decomposition of corn cob was influenced by temperature, precipitation, and frozen soil environment. The 150-day cumulative decomposition rates of the pith, woody ring, and glume were $40.0 \%, 24.2 \%$, and $36.3 \%$, respectively. Caused by the difference in fiber compositions, the decomposition speeds of pith and glume were much higher than that of the woody ring. The complex microstructures of the pith, woody ring, and glume led to differences in the accessibility of cellulose, which indirectly influenced the field decomposition characteristics. The homogeneous sponge-like structure of the pith and glume increased the accessibility of cellulose and ultimately accelerated the field decomposition, while the compact lignocellulosic structure of the woody ring hindered the decomposition process. Compared with corn stalk, corn cob had similar or even better field decomposition characteristics and excellent application prospects.
\end{abstract}

Keywords: sustainability of crop plants; corn cob; field decomposition; fiber composition; microstructure

\section{Introduction}

Corn is one of the world's three main grain crops and the largest grain crop in China. Corn cob is the essential by-product in corn production, which accounts for about $15 \%$ of the total mass with a moisture content ranging from $66 \%$ to $47 \%$ w.b. [1]. It is estimated that there are about $164 \mathrm{Tg}$ corn cobs produced globally each year [2] and $45.9 \mathrm{Tg}$ corn cobs produced annually in China. However, there are only about 8 million tons of corn cobs used in various applications. In total, $82.6 \%$ of the corn cobs are burned [3], which not only releases pollutants but also causes waste of biomass resources [4]. Returning to the field seems to be a reasonable treatment of corn cobs produced in harvesting.

At present, China's corn-harvesting technology is transforming from mechanized ear harvesting to corn kernel harvesting, especially in northeast China [5,6]. Generally, in northeast China, the corn kernel harvesting starts in early November, and the corn cobs are thrown into the field in the mechanized harvest. After harvesting, residues such as corn cobs on the ground are returned into the soil using turn-plow till sowing in early April of the following year. However, under the climate condition of low temperature in northeast China, the corn cobs decompose slowly after returning to the field, which causes short-term soil acidification [7], affects crop root development, aggravates pests and diseases, and reduces the quality of spring sowing [8,9]. Therefore, in order to improve soil physical and chemical properties [10], combat soil erosion [11], promote crop growth, and increase crop 
yield [12,13], it is of great significance to explore the field decomposition characteristics of corn cobs under the conditions of corn kernel harvesting technology in northeast China.

In terms of the various residues collected from corn production, most research has focused on the field decomposition of corn stalk. Zhao et al. [14] simulated the accumulation and mineralization of organic carbon in chernozem under different stalk return methods after corn harvesting. Villamil et al. [15] investigated the effects of corn residue, tillage, and nitrogen rate on soil properties. Jia et al. $[16,17]$ indicated that standing corn residue can act as an effective way to control wind erosion and compared the effects of two major corn stalk management techniques on soil frost depth, snow depth, and soil heat flux in northeast China. Cao et al. [18] and Yu et al. [19] assessed the field decomposition of corn stalks in two areas to explore the decomposition characteristics of corn stalks under different conditions. However, as a kind of residue with a proportion second only to corn stalk, there are few studies on the field decomposition of corn cob.

As a valuable biomass resource, the structure and characteristics of corn cob have been studied by many domestic and foreign scholars. Anazodo et al. [20] divided the structure of corn cob into three layers and explored the mechanical properties of corn cob from quasi-static radical compression force-deformation curves. Takada et al. [21] and Lu et al. [22] examined the chemical compositions and characteristics of the three layers of corn cob. Pinto et al. $[23,24]$ described the macrostructure and microstructure of different components of corn cob and assessed its elementary chemical composition, density, water absorption, fire resistance, and thermal insulation capacity. Ji et al. [25] explored the impact and mechanism of mechanical fragmentation on microstructure features and enzymatic hydrolysis at different plant scales. The above studies generally concentrated on the inherent structure and properties of corn cob. There are no published reports documenting in detail the field decomposition of corn cob, especially associating the decomposition characteristics with the fiber compositions and microstructures.

Based on the above considerations, in this study, different components of corn cob were obtained by mechanical cutting pretreatment. Then, field decomposition tests were conducted to analyze the decomposition characteristics of corn cob and to compare them with the field decomposition characteristics of corn stalk. Finally, the influences of fiber composition and microstructure on the field decomposition characteristics were explored by Fourier-transform infrared spectroscopy and scanning electron microscopy. The results can provide a theoretical basis for accelerating the field decomposition process of corn cob and developing corn-cob-crushing devices suitable for a corn kernel harvester.

\section{Materials and Methods}

\subsection{Material Preparation}

The corn variety used in the test was Feitian 358, which is a typical early maturing spring corn variety in northeast China and suitable for corn kernel harvesting technology. The experimental corn was acquired from Jilin University Agricultural Experiment Base $\left(43^{\circ} 56^{\prime} 46^{\prime \prime} \mathrm{N}, 125^{\circ} 14^{\prime} 52^{\prime \prime} \mathrm{E}\right)$ in October 2019. Mature corn ears were obtained by handpicking. Then, corn cobs without visual damage and degradation were obtained by manual threshing. After natural drying at a constant temperature $\left(23 \pm 1^{\circ} \mathrm{C}\right)$ and humidity $(60 \pm 5 \% \mathrm{RH})$, the average moisture content of the experimental corn cobs was $6.3 \%$ (wet basis), the average length was $190.8 \mathrm{~mm}$, the average diameter was $26.4 \mathrm{~mm}$, and the average mass was $20.2 \mathrm{~g}$.

The macroscopic structure of a corn cob can be divided into three layers, namely the pith, the woody ring, and the glume, as shown in Figure 1. The cross-section of the pith is an irregular circle, and its outer side is an annular woody ring and an annular glume. The middle 100-milllimeter portion of the experimental corn cob was cut off as the "whole corn $\mathrm{cob}^{\prime \prime}$, which was used as the control group of the field decomposition test. After that, the separated pith, woody ring, and glume were obtained by dividing the whole corn cob. The physical parameters of the different components of corn cob are shown in Table 1. 


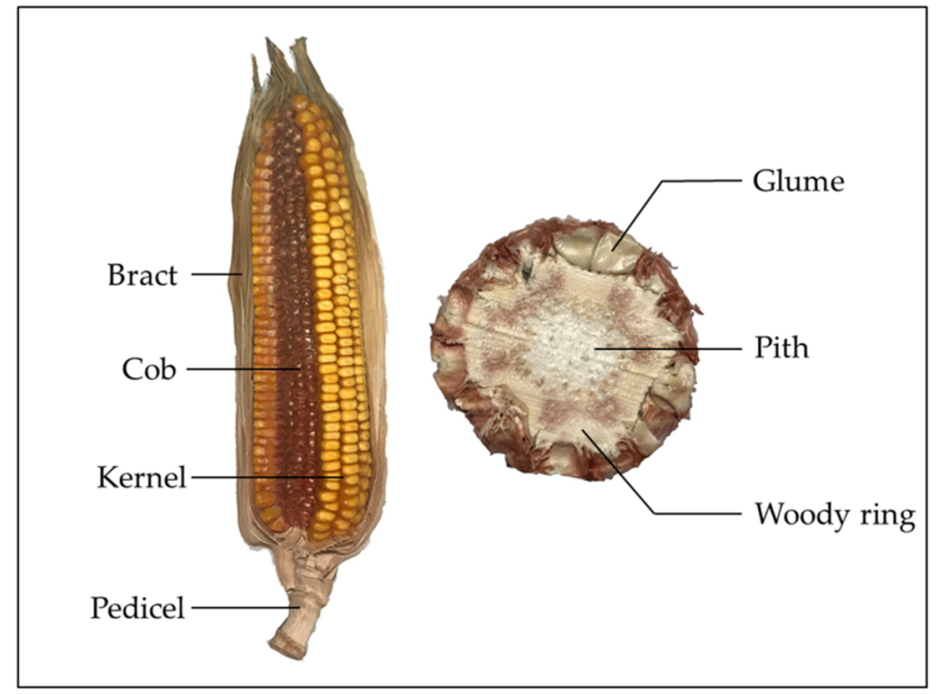

Figure 1. Layered structure of corn cob.

Table 1. Physical parameters of different components of corn cob (100 mm).

\begin{tabular}{|c|c|c|c|c|c|}
\hline Components & Mass/g & Volume $/ \mathrm{mm}^{3}$ & $\begin{array}{c}\text { Surface } \\
\text { Area } / \mathrm{mm}^{2}\end{array}$ & Density $/\left(\mathrm{g} / \mathrm{cm}^{3}\right)$ & $\begin{array}{c}\text { Water } \\
\text { Absorption/\% }\end{array}$ \\
\hline Pith & 0.3 & 66.5 & 2613.8 & 4.7 & $1935 \%$ \\
\hline Woody ring & 13.6 & 331.1 & 6762.4 & 40.9 & $216 \%$ \\
\hline Glume & 1.7 & 175.0 & $13,760.3$ & 9.7 & $356 \%$ \\
\hline
\end{tabular}

The soil used in the test was taken from Jilin University Agricultural Experiment Base at a depth of $20 \mathrm{~cm}$. After removing stones and roots, the soil was sieved using a sieve with an aperture of $2 \mathrm{~mm}$. The distributions by mass of particles of different sizes in the experimental soil were as follows: sand $(0.02 \sim 2 \mathrm{~mm}), 37.7 \%$; silt $(0.002 \sim 0.02 \mathrm{~mm}), 23.9 \%$; and clay $(0 \sim 0.002 \mathrm{~mm}), 38.5 \%$. The nutrient contents of the experimental soil as determined by a soil nutrient analyzer were as follows: organic matter, $21.6 \mathrm{~g} / \mathrm{kg}$; available nitrogen, $77.6 \mathrm{mg} / \mathrm{kg}$; available phosphorus, $18.2 \mathrm{mg} / \mathrm{kg}$; and available potassium, $83.2 \mathrm{mg} / \mathrm{kg}$. The saturated water capacity of the soil was $34.4 \%$, the bulk density was $1.37 \mathrm{~g} / \mathrm{cm}^{3}$, and the $\mathrm{pH}$ value was 6.4.

\subsection{Field Decomposition Tests}

The field decomposition tests of the corn cobs were carried out using the nylon mesh bag method. The whole corn cob, pith, woody ring, and glume were separately packed into nylon mesh bags with apertures of $0.4 \mathrm{~mm}$ ( $2 \mathrm{~g}$ for each bag and 100 bags for each type). After sealing, the mesh bags were embedded into the test boxes with prepared soil. The test boxes were $58.5 \mathrm{~cm}$ long, $44.6 \mathrm{~cm}$ wide, and $32.9 \mathrm{~cm}$ high. The experimental samples were buried at a depth of $20 \mathrm{~cm}$, and 10 bags of samples were buried in each box. To be consistent with the natural environment conditions of the field such as the temperature and precipitation, the test boxes were placed on the field surface at Jilin University Agricultural Experiment Base.

In northeast China, the field decomposition of corn cobs begins from the fall harvest (early November) to the spring sowing (early April of the following year). Therefore, the field decomposition period in this study was determined to be 150 days to cover all the decomposition periods in the field. The temperature and precipitation in the test area are shown in Figure 2 [26]. The thickness distribution of frozen soil in the test area is shown in Figure 3. Seasonally frozen soil appeared at the beginning of the tests. Subsequently, its thickness continued to spread deeper and deeper, reaching its maximum depth at day 120. After the 135th day, the frozen soil started to thaw from the field surface to the deeper 
layers. According to the characteristics of temperature and frozen soil, the decomposition process can be divided into three periods, which are the cooling period (1 November to 15 December), the frozen period (15 December to 28 February), and the thawing period (1 March to 1 April).

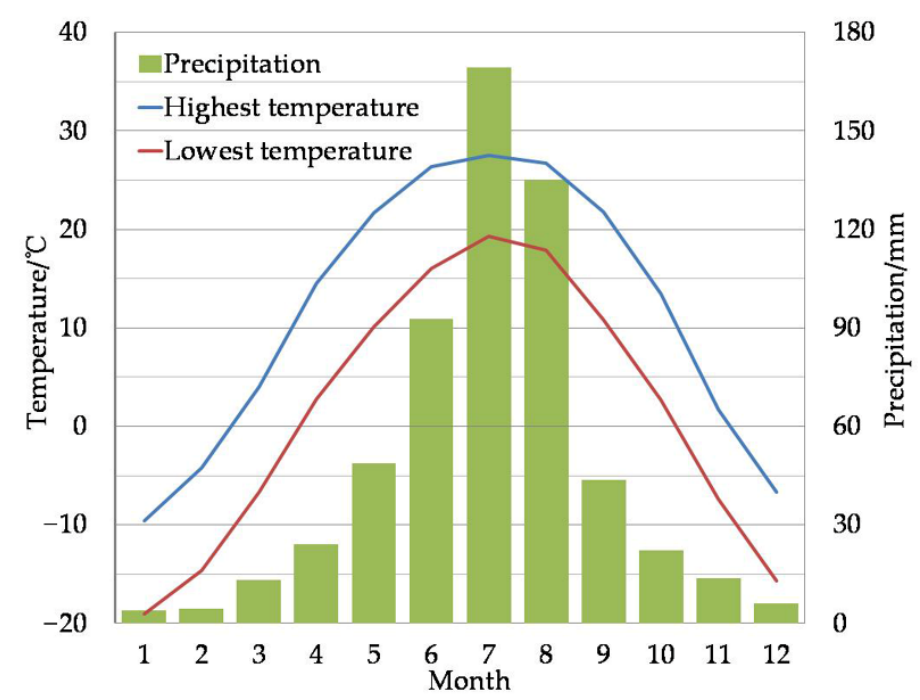

Figure 2. Temperature and precipitation in test area.

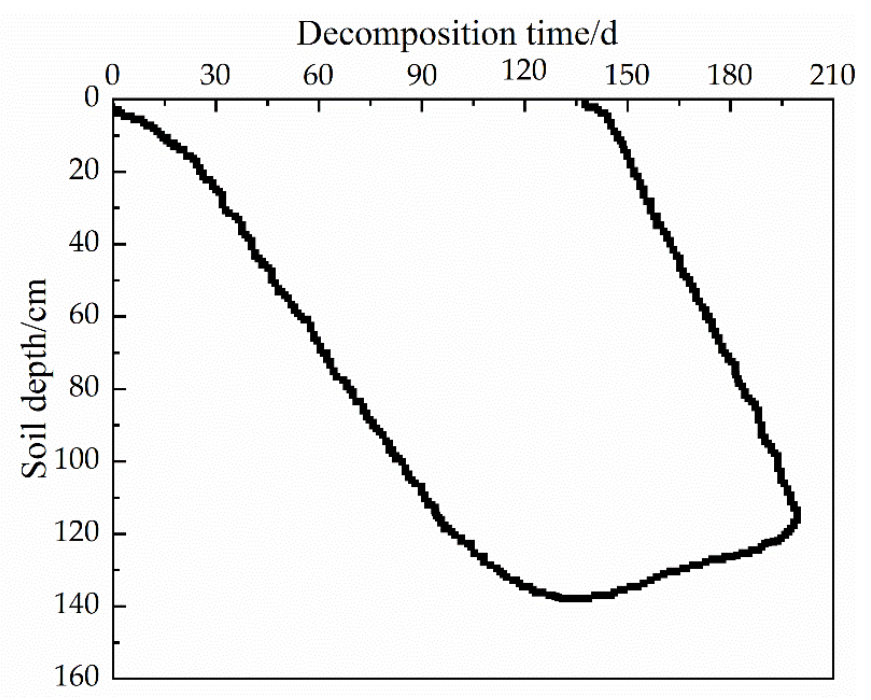

Figure 3. Profile of frozen soil thickness in test area.

The sampling interval of the field decomposition test was 15 days, and each group of samples was taken with 10 bags at a time. After sampling, the soil adhering to the surface of the experimental samples was washed. The experimental samples were dried at $105 \pm 2{ }^{\circ} \mathrm{C}$ for $24 \mathrm{~h}$ and weighed. The cumulative decomposition rate (\%) and decomposition speed $(\mathrm{g} / \mathrm{d})$, respectively, can be calculated by the following formulas:

$$
\begin{gathered}
R_{D}=\frac{M_{0}-M_{r}}{M_{0}} \times 100 \% \\
V_{D}=\frac{M_{0}-M_{r}}{T_{D}}
\end{gathered}
$$

where $R_{D}$ is the cumulative decomposition rate (\%); $M_{0}$ is the initial mass of the experimental sample (g); $M_{r}$ is the residual mass of the experimental sample $(\mathrm{g}) ; V_{D}$ is the decomposition speed $(\mathrm{g} / \mathrm{d}) ; T_{D}$ is the decomposition time $(\mathrm{d})$. 


\subsection{Infrared Spectrum Analysis}

As a kind of natural biomass, the material composition of corn cob heavily influences its field decomposition process. Fourier-transform infrared spectroscopy (FTIR) is an effective method for qualitative analysis of the compound composition of corn cob, especially the fiber composition. The pith, woody ring, and glume were dried in a drying oven at $105 \pm 2{ }^{\circ} \mathrm{C}$ for $24 \mathrm{~h}$. Afterward, these samples were ground into fine powder and made into observation tablets using the pressed-disk technique. Finally, a Shimadzu IRAffinity-1 Fourier Transform Infrared Spectrometer was used to analyze the prepared tablets in the wavelength range of $400 \sim 4000 \mathrm{~cm}^{-1}$.

\subsection{Microstructure Observation}

The microstructure of materials is also an important factor affecting field decomposition. In order to observe the microstructural forms and the densification properties of different components, microstructure observation was carried out. Before the observation, the samples were plated using a Cressington 108 automatic sputter coater after sufficient drying. After that, an EVO-18 scanning electron microscope (SEM) was used to observe the microstructures of the pith, woody ring, and glume. The microstructure observation was carried out at a lower acceleration voltage and as quickly as possible.

\section{Results and Discussion}

\subsection{Decomposition Characteristic Analysis}

It can be seen from Figure 4 that during the 150-day field decomposition process, the whole corn cob, pith, woody ring, and glume had similarities in their decomposition characteristics, which followed the pattern of first being fast, then slow, and ultimately accelerating gradually. The average decomposition speeds and cumulative decomposition rates of corn cob components are shown in Table 2. During the same period, piths had the highest cumulative decomposition rate, followed by glumes. The cumulative decomposition rates of the woody rings and whole corn cobs were the lowest in all periods and they were approximately equal. Regression analysis of field decomposition (Table 3) showed that fitting curves for the cumulative decomposition rate of the above samples conformed to the cubic polynomial distribution.

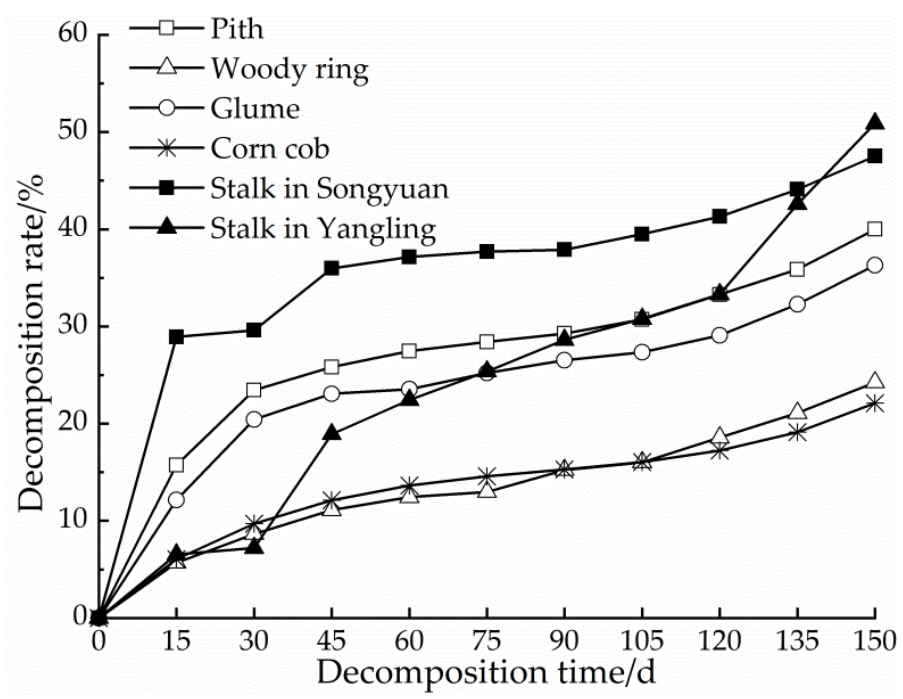

Figure 4. Field decomposition rate of corn cob. 
Table 2. Average decomposition speeds and cumulative decomposition rates of corn cob components.

\begin{tabular}{ccccc}
\hline & Components & Cooling Period & Frozen Period & Thawing Period \\
\hline \multirow{2}{*}{ Average decomposition } & Pith & 0.57 & 0.10 & 0.22 \\
speed/(\%/d) & Woody ring & 0.25 & 0.10 & 0.19 \\
& Glume & 0.51 & 0.08 & 0.24 \\
\hline \multirow{2}{*}{ Cumulative } & Pith & 25.8 & 33.3 & 40.0 \\
decomposition rate/\% & Woody ring & 11.1 & 18.6 & 24.2 \\
& Glume & 23.1 & 29.1 & 36.3 \\
\hline
\end{tabular}

Table 3. Regression analysis of field decomposition of corn cob.

\begin{tabular}{cccc}
\hline Components & Regression Equation & $\mathbf{R}^{\mathbf{2}}$ & Prediction of Decomposition Rate/\% \\
\hline Pith & $y=1.7587+0.95 x-0.01084 x^{2}+0.0000416979 x^{3}$ & 0.977 & 64.7 \\
Woody ring & $y=0.41438+0.36648 x-0.00365 x^{2}+0.0000151887 x^{3}$ & 0.995 & 36.7 \\
Glume & $y=0.93567+0.84281 x-0.00951 x^{2}+0.0000366835 x^{3}$ & 0.986 & 58.5 \\
Corn cob & $y=0.18043+0.43717 x-0.00457 x^{2}+0.0000175681 x^{3}$ & 0.999 & 33.3 \\
\hline
\end{tabular}

\subsubsection{Pith}

The decomposition speed of the pith was the fastest in the initial stage. The average decomposition speed of the pith in the cooling period was $0.57 \% / \mathrm{d}$, and the cumulative decomposition rate was $25.8 \%$. At this time, the average temperature of the test area was higher than $0{ }^{\circ} \mathrm{C}$, and the average precipitation was more than $10 \mathrm{~mm}$. After this period, the seasonally frozen soil in the test area gradually spread to $20 \mathrm{~cm}$ underground, which was the depth of the field decomposition test. Meanwhile, the precipitation at the test area also dropped to the lowest level of the year. The average decomposition speed of the pith during the frozen period decreased to $0.10 \% / \mathrm{d}$, the cumulative decomposition rate reached $33.3 \%$, and the net increase in the decomposition rate was $7.5 \%$. The average decomposition speed of the pith during the thawing period rose to $0.22 \% / \mathrm{d}$, the cumulative decomposition rate reached $40.0 \%$, and the net increase in the decomposition rate was $6.7 \%$. As the thawing period continued, the temperature and precipitation gradually increased. Based on the regression equation of the cumulative decomposition rate of piths, it can be predicted that the cumulative decomposition rate of piths would reach $64.7 \%$ as of $1 \mathrm{May}$, which was the spring sowing time in the northeast. At that time, the main structure of the piths would be completely decomposed and would not adversely affect the sowing.

\subsubsection{Woody Ring}

The decomposition characteristics of the woody rings followed the same pattern as those of the piths, but the cumulative decomposition rate of the woody ring was low for the whole period. The fitting degree of the cumulative decomposition rate of the woody ring was lower than that of the pith, and the decomposition speed fluctuated more. The average decomposition speed of the woody ring in the cooling period was $0.25 \% / d$, and the cumulative decomposition rate was $11.1 \%$. Then, the average decomposition speed in the frozen period reduced to $0.10 \% / \mathrm{d}$, and the cumulative decomposition rate increased to $18.6 \%$; the net increase in the decomposition rate was $7.5 \%$. In the thawing period, the average decomposition speed reached $0.19 \% / \mathrm{d}$, the cumulative decomposition rate reached $24.2 \%$, and the net increase in the decomposition rate was $5.6 \%$. According to the regression equation of the cumulative decomposition rate, it can be predicted that the cumulative decomposition rate of the woody ring would reach $36.7 \%$ on 1 May. At the time of spring sowing, the undecomposed woody ring would be the main residue in the field. It is also the main substance affecting corn emergence and seedbed stability.

\subsubsection{Glume}

The trend of the cumulative decomposition rate of the glumes was almost the same as that of the piths, but there was a slight difference. After the 15th day, the cumulative 
decomposition rate of the glumes was always about $3 \%$ lower than that of the piths. In other words, the decomposition speed of these two components of the corn cob was almost the same throughout the test period.

The average decomposition speeds of glume in the cooling period, frozen period, and thawing period were $0.51 \% / \mathrm{d}, 0.08 \% / \mathrm{d}$, and $0.24 \% / \mathrm{d}$, respectively. The cumulative decomposition rates were $23.1 \%, 29.1 \%$, and $36.3 \%$, respectively. According to the regression equation of the decomposition rate, it can be predicted that the cumulative decomposition rate of the glume could reach $58.5 \%$ on 1 May.

\subsubsection{Overall Analysis and Comparison}

Under the same soil environment and climate conditions, the average decomposition speeds and cumulative decomposition rates of the whole corn cob, pith, woody ring, and glume showed significant differences. As can be seen from Figure 4, the cumulative decomposition rates of the pith, woody ring, and glume in 150 days were $40.0 \%, 24.2 \%$, and $36.3 \%$, respectively. Compared with the whole corn cob, the cumulative decomposition rates were increased by $81 \%, 10 \%$, and $64 \%$, respectively.

As a residue produced simultaneously with corn cob in mechanized corn harvesting, the field decomposition characteristics of corn stalk have been investigated by many scholars. Field decomposition characteristics of corn stalk in Songyuan, Jilin Province $\left(45^{\circ} 26^{\prime} 64^{\prime \prime} \mathrm{N}\right.$, $\left.124^{\circ} 87^{\prime} 69^{\prime \prime} \mathrm{E}\right)$, and that in Yangling, Shaanxi Province $\left(34^{\circ} 17^{\prime} 51^{\prime \prime} \mathrm{N}, 108^{\circ} 00^{\prime} 48^{\prime \prime} \mathrm{E}\right.$ ), were selected for comparison $[18,19]$. The locations of the field decomposition tests are shown in Figure 5. Among them, field decomposition of corn stalk in Songyuan began on 25 April and lasted for 150 days. Field decomposition of corn stalk in Yangling began on 31 October and lasted for 300 days, but only the decomposition in the first 150 days was selected for comparison.

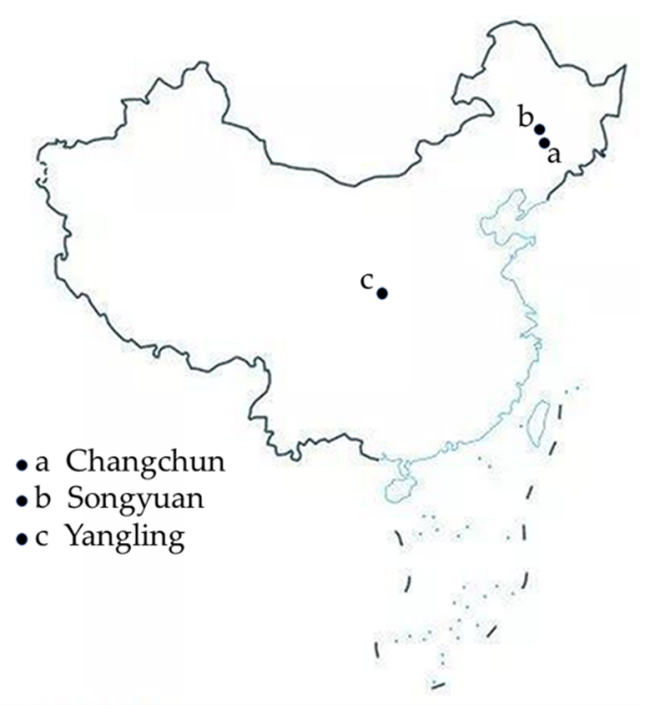

Figure 5. Location of field decomposition tests.

For comparison, the corn stalks of Songyuan and the corn cobs of Changchun were decomposed for 150 days in the field in summer and winter, respectively. Although the sites and soil environments were similar, there were significant differences in the cumulative decomposition rate and decomposition speed. It can be seen that differences in temperature and precipitation can significantly affect the field decomposition speed in different seasons. Yangling's corn stalks and Changchun's corn cobs decomposed in the field for 150 days in winter. In the first 30 days, as the precipitation levels were approximately the same and the temperatures were around $0{ }^{\circ} \mathrm{C}$, the field decomposition speeds were approximately the same. After 30 days, the temperature in Yangling remained at a certain level, while the temperature in Changchun continued to decrease. Seasonally frozen soil appeared, and field decomposition entered the frozen period. In the frozen period, the field decomposition 
speed in Changchun was significantly lower than that in Yangling, indicating that the seasonally frozen soil greatly hindered the process of field decomposition. Then, from the thawing period to spring sowing, the field decomposition speed returned to normal. It is worth noting that the decomposition speeds of the pith and glume were significantly higher than that of the corn stalk. Compared with corn stalk, corn cob had similar or even better field decomposition characteristics.

\subsection{Effect of Fiber Composition on Field Decomposition}

As an enzymatic reaction with the participation of microorganisms, the field decomposition characteristics of corn cob are influenced by its chemical composition, especially the fiber composition. Corn cob is mainly composed of cellulose, hemicellulose, and lignin. The contents of these fiber components in the pith, woody ring, and glume are different, which indirectly affects the field decomposition characteristics of corn cob. Fourier-transform infrared spectroscopy was used for qualitative analysis of the fiber compositions in the pith, woody ring, and glume, and the results are shown in Figure 6.

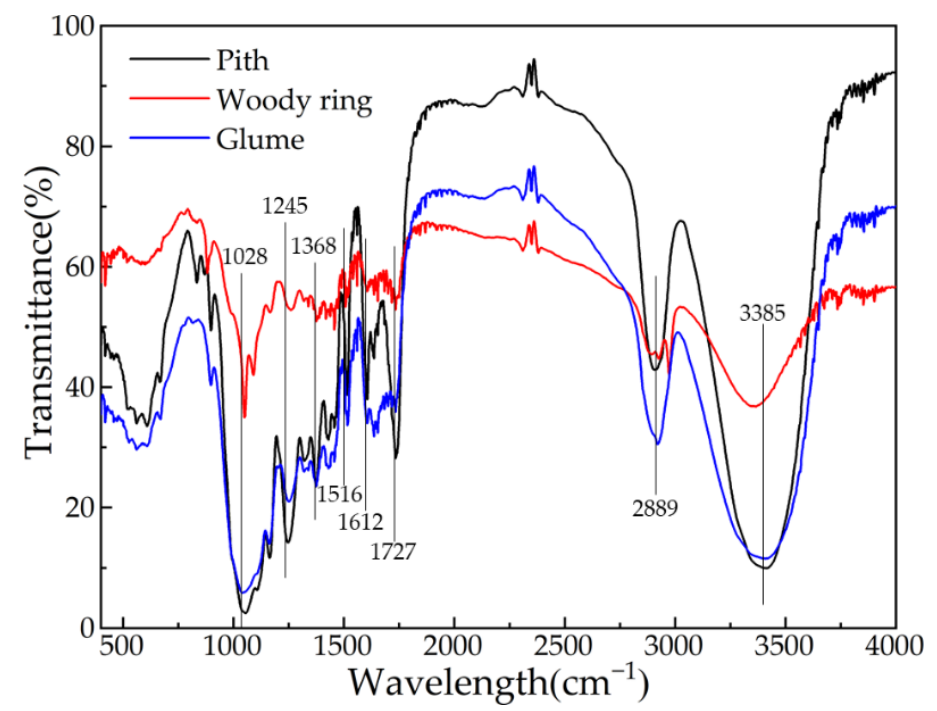

Figure 6. FTIR of three-layer components of corn cob.

According to the attribution analysis of the FTIR in Figure 6 and Table 4, the transmittances of pith, woody ring, and glume were different, but the trends were roughly the same. Among them, the absorption peaks related to cellulose mainly appeared around $1028,1245,2889$, and $3385 \mathrm{~cm}^{-1}$. The absorption peaks at 1028 and $2889 \mathrm{~cm}^{-1}$ represented the stretching vibration of $\mathrm{C}-\mathrm{O}-\mathrm{C}$ and $\mathrm{C}-\mathrm{H}$ groups, respectively, while the absorption peaks at $1245 \mathrm{~cm}^{-1}$ represented the bending vibration of $\mathrm{O}-\mathrm{H}$ [27]. The absorption peaks near $3385 \mathrm{~cm}^{-1}$ were the descending stretch in cellulose. The absorption peaks around 1516 and $1612 \mathrm{~cm}^{-1}$ were mainly derived from lignin aromatic skeletal vibration and $C=O$ stretching [28]. The transmittances of the absorption peaks here were as follows: woody ring > pith > glume. The absorption peaks at $1727 \mathrm{~cm}^{-1}$ were the main characteristic peaks that distinguished hemicellulose from other components and represented the $\mathrm{C}=\mathrm{O}$ stretching vibration of the acetyl group and carboxyl group in hemicellulose [29]. The absorption peaks near $1368 \mathrm{~cm}^{-1}$ represented the bending vibration of C-H groups, which existed in cellulose and hemicellulose simultaneously. 
Table 4. Functional groups of FTIR of different fiber components.

\begin{tabular}{cc}
\hline Wavelength/cm & Functional Groups \\
\hline 1028 & C-O stretching vibration in cellulose \\
1245 & $-\mathrm{OH}$ bending vibration in cellulose \\
1368 & C-H bending vibration in cellulose and hemicellulose \\
1516 & Aromatic skeletal vibration \\
1612 & Aromatic skeletal vibration plus C=O stretching \\
1727 & $\mathrm{C}=\mathrm{O}$ stretching vibration in hemicellulose \\
2889 & $\mathrm{C}-\mathrm{H}$ stretching vibration in cellulose \\
3385 & $-\mathrm{OH}$ descending stretch in cellulose \\
\hline
\end{tabular}

As early as the last century, Lu et al. [22] had subdivided the structure of the corn $\mathrm{cob}$ and determined the fiber compositions of each component. The contents of cellulose, hemicellulose, and lignin measured by Lu et al. are shown in Table 5. It can be seen from the table that the hemicellulose content was the highest in the pith and glume, while the cellulose content was slightly lower than the hemicellulose content. Cellulose was the most abundant fiber type in the woody ring, and its content was much higher than that of hemicellulose. Furthermore, the content of lignin in the woody ring was higher than that in the pith and glume, which may be one of the reasons for the differences in decomposition characteristics.

Table 5. Fiber composition of corn cob (\%, dry basis).

\begin{tabular}{cccc}
\hline Components & Lignin & Cellulose & Hemicellulose \\
\hline Pith and glume & 5.4 & 35.7 & 37.0 \\
Woody ring & 6.8 & 47.1 & 37.3 \\
\hline
\end{tabular}

Cellulose is the most abundant polymer in corn cobs. As the structural polysaccharide of the cell wall of corn cob, it accounts for 30 50\% of the total fiber composition. Hemicellulose is second only to cellulose in the fiber composition of corn cob, accounting for 30 40\% of the total fiber composition. Hemicellulose is usually used as the adhesive to connect cellulose microfibers in corn cob. The strength of the chemical bonds in hemicellulose is lower than that in cellulose, and FTIR shows that there are fewer chemical bonds in hemicellulose than in cellulose. The degree of polymerization of hemicellulose is also significantly lower than that of cellulose. As a result of this, hemicellulose is the first fiber to decompose in corn cob, and its cumulative decomposition rate is also higher than that of cellulose [30]. The content of lignin in corn cob is about $5 \sim 10 \%$, and the main function of lignin is to strengthen the connection between cellulose microfibrils and enhance the mechanical strength of fiber structure. During the field decomposition process, the presence of lignin seriously hindered the decomposition of fiber structures in corn cob, mainly in the following aspects: (1) Lignin has steric hindrance in the enzymatic hydrolysis of cellulose by cellulase; (2) lignin has some ineffective adsorption to cellulase; and (3) the products of enzymatic hydrolysis of lignin are toxic to microorganisms [31].

In terms of different experimental samples, the relative contents of hemicellulose in the pith and glume were higher than that in the woody ring, so the decomposition speeds of the pith and glume were higher than that of the woody ring in the cooling period. For different fiber compositions, when the corn cob was decomposed in the field, the decomposition process of cellulose and hemicellulose generally followed the trend of "first fast and then slow", and the decomposition speed and cumulative decomposition rate of hemicellulose were higher than those of cellulose from beginning to end. Due to the hindrance of lignin in field decomposition, the decomposition speed of lignin was the slowest, and there was no obvious speed fluctuation in the whole process. Therefore, lignin was the main fiber type that needed to be decomposed in the late stage of field decomposition, and it was also the main component that remained in the field. 
Considering that the field decomposition of lignin was very slow, the decomposition speed of lignin could be increased by additional means to ultimately accelerate the overall decomposition process of corn cob. For instance, a decomposing agent or lignin-decomposing enzyme can be applied in the process of returning cobs to the field, allowing rapid decomposition of lignin in the early stages of field decomposition and reducing the impact of steric hindrance and ineffective adsorption of lignin. In addition, lignin-decomposing microorganisms, such as white-rot fungi, actinomycetes, and some bacteria, can be added to the field to fully decompose lignin during the entire period of field decomposition.

\subsection{Effect of Microstructure on Field Decomposition}

The microstructure was also a key factor affecting the decomposition characteristics; in other words, fiber accessibility was the decisive factor affecting the field decomposition speed [32]. The complex microstructures of the three components of corn cob made their specific surface areas and cellulose accessibility different, which eventually led to the differences in decomposition speed. The microstructures of the different components of corn cob were obtained by SEM, and the results are shown in Figure 7. As shown in the SEM images, the microstructures of the different components of corn cob are quite different.

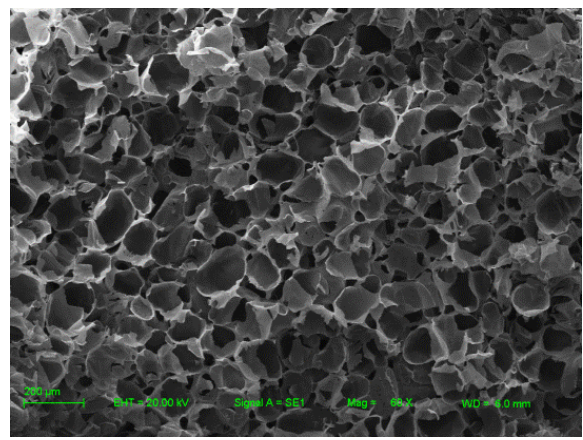

(a)

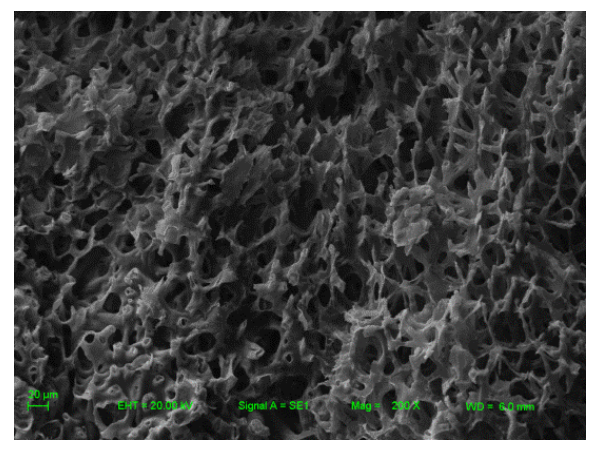

(b)

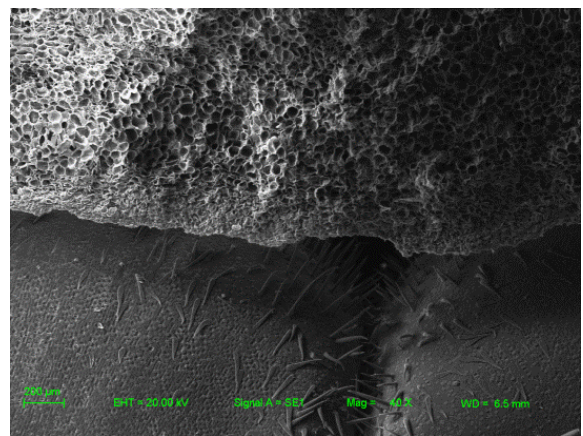

(c)

Figure 7. Microstructure of different components of corn cob. (a) Microstructure of pith; (b) microstructure of woody ring; (c) microstructure of glume and its connection to woody ring.

The microstructure of the pith (Figure 7a) is a homogenous sponge-like tissue with thin walls and full of air. The cells are so tightly connected that there are almost no gaps. This sponge-like microstructure gives it a low density, good water and oil absorption ability, and a large specific surface area for cellulose. During field decomposition, the high specific surface area of the pith made the contact between cellulose and microorganisms more adequate and accelerated the decomposition speed.

As an important plant organ, the microstructure and physico-chemical properties of corn cob share many similarities with cork, mainly in the woody ring. The macroscopic texture and strength of the woody ring are similar to those of cork [24], making the woody ring the main source of density and mass of the corn cob. The pith and woody ring are connected by internodal tissues. The woody ring (Figure $7 \mathrm{~b}$ ) has a compact homogeneous microstructure with a higher density than the pith. Its microstructure is a hollow tubular structure with cellulose as the skeleton, which is filled and bonded by lignin. The cellulose skeletons interweave as a whole to form a compact three-dimensional network entity. In the woody ring, lignin strengthens the connection between cellulose microfibrils, creating the space barrier between microbial enzymes and cellulose, reducing the accessibility of cellulose, and ultimately reducing the decomposition speed of the woody ring.

Glume is the connection between the corn cob and corn kernels, which is a kind of degenerated plant tissue. As can be seen in Figure 7c, the connection between the glume and woody ring is not transitional, but rather a well-defined embedded connection. Like 
the pith, the internal microstructure of the glume is also a porous cellular structure, with the main difference being the distribution of many transparent glandular hairs and elliptical protrusions on the outer surface of the glume. The loose and complex microstructures of the pith and glume make the corn cob maintain good physical properties and structural integrity while having much higher absorption characteristics than other agricultural materials do.

Furthermore, in the determination of water absorption, we found that although the macroscopic structure of corn cob is relatively loose, its water absorption process is a slow progressive saturation. It can be speculated that corn cobs may have a capillary-like structure, making their water absorption process similar to osmosis. This kind of porous cellular microstructure and capillary-like structure also have an important influence on the field decomposition of corn cob.

Therefore, using physical, chemical, and biological means to destroy the fiber structure of the corn cob and improve the accessibility of cellulose is of great significance to promote the field decomposition of corn cob.

\section{Conclusions}

In this study, field decomposition tests were carried out to investigate the decomposition characteristics of different components of corn cob under seasonally frozen soil conditions. After that, the effects of fiber compositions and microstructures on field decomposition were explored by FTIR and SEM, respectively. The results can be summarized as follows:

The field decomposition of corn cob followed the pattern of first being fast, then slow, and ultimately accelerating gradually. The decomposition speed order was as follows: pith $>$ glume $>$ woody ring, and the cumulative decomposition rates of the pith, woody ring, and glume were $40.0 \%, 24.2 \%$, and $36.3 \%$, respectively. The fiber components of corn cob greatly affected its field decomposition process. Among them, hemicellulose was the first fiber component to decompose, followed by cellulose. The presence of lignin severely hindered field decomposition. The complex microstructures of the three components made the cellulose accessibility different, which eventually led to the difference in decomposition speed.

Compared with corn stalk, corn cob has better field decomposition characteristics and excellent prospects. This study can provide a theoretical basis for the field decomposition of agricultural residues in seasonally frozen soil.

Author Contributions: Conceptualization, J.F.; methodology, J.F.; validation, Y.Z.; investigation, Y.Z.; resources, J.F.; writing—original draft preparation, Y.Z.; writing—review and editing, J.F.; supervision, Z.C. and L.R.; project administration, J.F.; funding acquisition, J.F. All authors have read and agreed to the published version of the manuscript.

Funding: This research was funded by the International Science and Technology Cooperation Project of Jilin Provincial Science and Technology Development Program (No. 20190701055GH).

Institutional Review Board Statement: Not applicable.

Informed Consent Statement: Not applicable.

Data Availability Statement: Some or all data, models, or code generated or used during the study are available from the corresponding author by request.

Acknowledgments: The authors are grateful for the corn provided by the Jilin University Agricultural Experiment Base and the equipment provided by the Key Laboratory of Bionic Engineering, Ministry of Education.

Conflicts of Interest: The authors declare no conflict of interest. The funders had no role in the design of the study; in the collection, analyses, or interpretation of data; in the writing of the manuscript, or in the decision to publish the results. 


\section{References}

1. Igathinathane, C.; Womac, A.; Sokhansanj, S. Corn stalk orientation effect on mechanical cutting. Biosyst. Eng. 2010, 107, 97-106. [CrossRef]

2. Takada, M.; Niu, R.; Minami, E.; Saka, S. Two-step hydrolysis of corn (Zea mays) cobs treated with semi-flow hot-compressed water. Int. J. Agric. Crop Sci.. in press.

3. Wang, H.; Zhang, X.; Wang, D.; Cui, C.; Gao, C.; Wang, L.; Wang, Y.; Bi, Y. Estimation and utilization of corn cob resources in China. Chin. J. Agric. Resour. Reg. Plan. 2016, 37, 1-8.

4. Hong, J.; Ren, L.; Hong, J.; Xu, C. Environmental impact assessment of corn straw utilization in China. J. Clean. Prod. 2016, 112, 1700-1708. [CrossRef]

5. Chen, Z. Maize Full Value Harvest Key Technology and Equipment; Science Press: Beijing, China, 2014; pp. 1-181.

6. Yang, L.; Cui, T.; Qu, Z.; Li, K.; Yin, X.; Han, D.; Yan, B.; Zhao, D.; Zhang, D. Development and application of mechanized maize harvesters. Int. J. Agric. Biol. Eng. 2016, 9, 15-28.

7. Zhu, Q.; Liu, X.; Hao, T.; Zeng, M.; Shen, J.; Zhang, F.; De Vries, W. Modeling soil acidification in typical Chinese cropping systems. Sci. Total Environ. 2018, 613-614, 1339-1348. [CrossRef]

8. Christian, D.; Bacon, E.; Brockie, D.; Glen, D.; Gutteridge, R.; Jenkyn, J. Interactions of Straw Disposal Methods and Direct Drilling or Cultivations on Winter Wheat (Triticum aestivum) grown on a Clay Soil. J. Agric. Eng. Res. 1999, 73, 297-309. [CrossRef]

9. Zhao, J.; Huang, D.; Jia, H.; Zhuang, J.; Guo, M. Analysis and experiment on cutting performances of high-stubble maize stalks. Int. J. Agric. Biol. Eng. 2017, 10, 40-52.

10. Xiu, L.; Zhang, W.; Sun, Y.; Wu, D.; Meng, J.; Chen, W. Effects of biochar and straw returning on the key cultivation limitations of Albic soil and soybean growth over 2 years. Catena 2019, 173, 481-493. [CrossRef]

11. Toure, A.A.; Rajot, J.L.; Garba, Z.; Marticorena, B.; Petit, C.; Sebag, D. Impact of very low crop residues cover on wind erosion in the Sahel. Catena 2011, 85, 205-214. [CrossRef]

12. Madar, R.; Singh, Y.; Meena, M.; Das, T.; Paramesh, V.; Al-Mana, F.; Mattar, M.A.; Elansary, H.O. Residue and Potassium Management Strategies to Improve Crop Productivity, Potassium Mobilization, and Assimilation under Zero-Till Maize-Wheat Cropping System. Agriculture 2020, 10, 401. [CrossRef]

13. Zhu, K.; Liu, Z.; Tan, X.; Lin, J.; Xu, D. Study on the ecological potential of Chinese straw resources available for bioenergy producing based on soil protection functions. Biomass Bioenergy 2018, 116, 26-38. [CrossRef]

14. Zhao, X.; He, L.; Zhang, Z.; Wang, H.; Zhao, L. Simulation of accumulation and mineralization $\left(\mathrm{CO}_{2}\right.$ release) of organic carbon in chernozem under different straw return ways after corn harvesting. Soil Tillage Res. 2016, 156, 148-154. [CrossRef]

15. Villamil, M.B.; Little, J.; Nafziger, E.D. Corn residue, tillage, and nitrogen rate effects on soil properties. Soil Tillage Res. 2015, 151, 61-66. [CrossRef]

16. Jia, H.; Wang, G.; Guo, L.; Zhuang, J.; Tang, L. Wind erosion control utilizing standing corn residue in Northeast China. Soil Tillage Res. 2015, 153, 112-119. [CrossRef]

17. Wang, G.; Jia, H.; Tang, L.; Lu, Y.; Guo, L.; Zhuang, J. Standing corn residue effects on soil frost depth, snow depth and soil heat flux in Northeast China. Soil Tillage Res. 2017, 165, 88-94. [CrossRef]

18. Cao, Y.; Zhang, H.; Liu, K.; Lv, J. Decomposition Characteristics of Crop Residues among Different Agricultural Treatments. Trans. Chin. Soc. Agric. Mach. 2016, 47, 212-219.

19. Yu, H.; Gu, Y.; Liang, X.; Wu, C. Study on the Decomposition Characteristics of Maize Straw and Soil Microbial Functional Diversity. J. Soil Water Conserv. 2015, 29, 305-309.

20. Anazodo, U.; Norris, E. Effects of genetic and cultural practices on the mechanical properties of corn cobs. J. Agric. Eng. Res. 1981, 26, 97-107. [CrossRef]

21. Takada, M.; Niu, R.; Minami, E.; Saka, S. Characterization of three tissue fractions in corn (Zea mays) cob. Biomass Bioenergy 2018, 115, 130-135. [CrossRef]

22. Lu, M.; Li, J. The properties of corn cob and the way of deep processing. Food Ind. 1995, 4, 30-33.

23. Pinto, J.; Paiva, A.; Varum, H.; Costa, A.; Cruz, D.; Pereira, S.; Fernandes, L.; Tavares, P.; Agarwal, J. Corn's cob as a potential ecological thermal insulation material. Energy Build. 2011, 43, 1985-1990. [CrossRef]

24. Pinto, J.; Cruz, D.; Paiva, A.; Pereira, S.; Tavares, P.; Fernandes, L.; Varum, H. Characterization of corn cob as a possible raw building material. Constr. Build. Mater. 2012, 34, 28-33. [CrossRef]

25. Ji, G.; Gao, C.; Xiao, W.; Han, L. Mechanical fragmentation of corncob at different plant scales: Impact and mechanism on microstructure features and enzymatic hydrolysis. Bioresour. Technol. 2016, 205, 159-165. [CrossRef]

26. China Meteorological Administration. Available online: https://weather.cma.cn/web/weather/54161.html (accessed on 12 May 2021).

27. Ganguly, P.; Sengupta, S.; Das, P.; Bhowal, A. Valorization of food waste: Extraction of cellulose, lignin and their application in energy use and water treatment. Fuel 2020, 280, 118581. [CrossRef]

28. Araya, J.A.; Carneiro, R.L.; Freer, J.; Neira, J.Y.; Castillo, R.D.P. Fourier transform infrared imaging and quantitative analysis of pre-treated wood fibers: A comparison between partial least squares and multivariate curve resolution with alternating least squares methods in a case study. Chemom. Intell. Lab. Syst. 2019, 195, 103890. [CrossRef]

29. Yang, B.; Zhang, S.; Hu, H.; Duan, C.; He, Z.; Ni, Y. Separation of hemicellulose and cellulose from wood pulp using a $\gamma$-valerolactone (GVL)/water mixture. Sep. Purif. Technol. 2020, 248, 117071. [CrossRef] 
30. Agbor, V.B.; Cicek, N.; Sparling, R.; Berlin, A.; Levin, D.B. Biomass pretreatment: Fundamentals toward application. Biotechnol. Adv. 2011, 29, 675-685. [CrossRef] [PubMed]

31. Donohoe, B.S.; Decker, S.R.; Tucker, M.P.; Himmel, M.E.; Vinzant, T.B. Visualizing lignin coalescence and migration through maize cell walls following thermochemical pretreatment. Biotechnol. Bioeng. 2008, 101, 913-925. [CrossRef]

32. Meng, X.; Ragauskas, A.J. Recent advances in understanding the role of cellulose accessibility in enzymatic hydrolysis of lignocellulosic substrates. Curr. Opin. Biotechnol. 2014, 27, 150-158. [CrossRef] 